$14^{\text {th }}$ Conf. Agric. Develop. Res., Fac. of Agric., Ain Shams Univ.,

March, 2019, Cairo, Egypt

Special Issue, 27(1), 1-15, 2019

Website: http://strategy-plan.asu.edu.eg/AUJASCI/

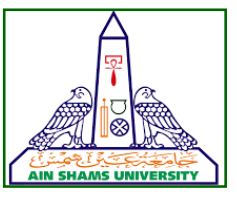

\title{
EFFECT OF ASCORBATE, SALICYLATE AND SILICATE ON POTATO PLANT UNDER WATER DEFICIT STRESS CONDITIONS
}

\author{
Amal A. Mostafa ${ }^{1}$, Sarwat M.I. ${ }^{2}$, Dawlat A. Salama ${ }^{2}$ and Sallam, H.A. ${ }^{1}$ \\ 1. Plant Genetic Resources Dept., Desert Research Center, Cairo, Egypt. \\ 2. Agric. Biochemistry Dept., Fac. of Agric., Ain Shams Univ., P.O. Box 68, Hadyak, \\ 11241,Cairo, Egypt.
}

*Corresponding author: amala.mostafa@gmail.com

Received 9 October, 2018,

Accepted 28 October, 2018

\begin{abstract}
The effect of different concentrations of ascorbate (As) at $0,0.25,0.5$ and $1.0 \mathrm{mM}$, salicylate (Sa) at $0,0.25,0.5$ and $1.0 \mathrm{mM}$, in addition to silicate $(\mathrm{Si})$ at $0,100,250$, and $500 \mathrm{ppm}$ on potato plant subjected to different water regimes; three days interval (control), four days interval (4DI) and five days interval (5DI). Photosynthetic pigments, free proline and malonyldialdehyde (MDA) concentrations, and plant dry matter percentage were determined. Also, tuber yield was recorded and the percentage of tuber dry matter was determined.

Water deficit resulted in significant reduction in tuber yield, plant dry matter percentage beside significant increase in free proline and MDA contents. Meanwhile, effects on photosynthetic pigments content and tuber dry matter were inconsistent. The effects of using different concentrations of ascorbate (As) under water deficit provide a superior effect of As at $0.25 \mathrm{mM}$. Data revealed that ascorbate treatment enhanced tuber yield by improved Chl ( $\mathrm{a}$ and $\mathrm{b}$ ) and carotenoids content, with a promoted reduction in free proline content and MDA.

Salicylate (Sa) treatment under water deficit exhibited partial enhancement in photosynthetic pigments; where, Sa $(1.0 \mathrm{mM})$ increased $\mathrm{Chl}$ a under all water regimes and $\mathrm{Chl} b$ at control and 4DI water regimes. While Sa $(0.5 \mathrm{mM})$ improved carotenoids content at $5 \mathrm{DI}$ water regimes. The positive effect of salicylate on tuber yield was obvious only at 5DI water regime; as salicylate concentrations $(0.25,0.5$ and $1.0 \mathrm{mM})$ enhanced tuber yield by $65.61,21.8$ and $33.33 \%$. Data exhibited that these increments were concomitant with a
\end{abstract}

reduction in free proline content and a slight increase in tuber dry matter.

Interactive effects of Silicate (Si)/water deficit were variable with the concentration under the used water deficit regimes, where, Si (100 ppm), showed higher means of $\mathrm{Chl}(\mathrm{a}$ and $\mathrm{b}$ ) with a reduction in free proline contents, at both 4DI and $5 \mathrm{DI}$. The higher tuber yield resulted only at 5DI. More pronounced effect, Si (250 ppm) exhibited increment of photosynthetic pigments, plant dry matter, tuber yield, along with slight reduction in MDA, particularly at 5DI. It could be concluded that silicate treatment alleviated water stress by improving carotenoids content, plant dry matter and reducing both free proline and MDA contents, which attributes enhancement in tuber yield under water deficit. Generally, lower concentrations of As, Sa and $\mathrm{Si}$ showed their benefits under higher water stress regimes.

Key words: malonyldialdehyde, photosynthetic pigments, proline, Solanum tuberosum, tuber yield.

\section{INTRODUCTION}

Among abiotic stress factors, drought is the most critical threat facing agriculture sector. Also, it is exacerbating the effect of other stresses to which plants are subjected (abiotic or biotic) (Cruz de Carvalho, 2008). For rapidly increasing population and limitation of water resources, minimizing effects of drought is indispensable. Currently, there are no economically viable technological means to facilitate crop production under drought stress. Development of crops for enhanced drought resistance requires the knowledge of biochemical 
and physiological mechanisms of the contributing traits.

Drought stress results in oxidative damage to the cell biological molecules due to the overproduction of reactive oxygen species (ROS). ROS can oxidize multiple cellular components like proteins and lipids, DNA and RNA. Unrestricted oxidation of cellular components ultimately causes cell death (Cruz de Carvalho, 2008).

Ascorbic acid (As) is an antioxidant molecule and a key substrate for the detoxification of ROS (Foyer and Noctor, 2011). Physiologically active form of As is the resonance stabilized anionic form, which is termed as ascorbate. Exogenous application of As can protect lipids and proteins against drought-induced oxidative adversaries ( $\mathrm{Naz}$ et al 2016). Ascorbic acid could improve tolerance against abiotic stresses by enhancing plant growth, rate of photosynthesis and photosynthetic pigments, transpiration, and oxidative defense potential. It is reported that ascorbate can effectively regulate anti-oxidative metabolism in plants (Noctor et al 2014). Also, endogenous As levels could be improved by exogenous application of As (Athar et al 2008).

Salicylic acid (Sa) is a naturally occurring as phenolic compound and endogenously synthesized as signaling molecule in plants. Salicylic acid role in competing various biotic and abiotic stresses was reported, however, the basic biochemical, physiological and molecular mechanisms that potentially underpin, Sa-induced plant-tolerance to abiotic stresses remains least discussed (Khan et al 2015). Salicylic acid regulates important plant physiological processes such as photosynthesis, nitrogen metabolism, proline metabolism, antioxidant defense system, and plant-water relations, with concomitant protection in plants against abiotic stresses (Khan et al 2012).

Silicon ( $\mathrm{Si}$ ) is the second most abundant element in the Earth's crust (Ma and Yamaji 2006). It is used to improve plant abiotic/biotic stress tolerance (Zhu and Gong, 2014). Previous studies have been concentrating on Si's role in Si accumulator plants, while little information is available on its role in Si non-accumulator plants (Shi et al 2016). Alleviation of drought stress by silicon supplementation was observed in tomato (Silva et al 2012).

This study aimed to evaluate the influences of As, Sa and Si on potato plant (Solanum tuberosum L. cv. Spunta) grown under water deficit regimes in Al-Qantra Sharq, Sahl-Eltina, North Sinai Governorate.

\section{MATERIALS AND METHODS}

An open field trial was conducted in a private farm located in Al Qantra Sharq, Sahl-Eltina, North Sinai Governorate during 2014 winter season to study the role of ascorbate, salicylate and silicate in ameliorating drought stress in potato plant (Solanum tuberosum L. cv. Spunta).

Field was prepared using conventional practices recommended for potato production. Potato (cv. Spunta) tubers were cut and sown in furrows in November, 2014. Sprinkler irrigation system was used for watering the experiment and water deficit regimes were achieved through withholding irrigation, i.e. three days interval (control), four days interval (4DI), and five days interval (5DI).

Forty days-old potato plants were sprayed with ascorbate (As) at (0, 0.25, 0.5 and $1.0 \mathrm{mM})$, salicylate $(\mathrm{Sa})$ at $(0,0.25,0.5$ and $1.0 \mathrm{mM})$, and silicate (Si) at $(100,250$, and 500 ppm) in forms of potassium salts Concept protect consisting of $21 \%$ soluble silicate and $12.4 \%$ potassium oxide was used as a source of silicate.

Plant samples were collected 15 days after exogenously applying the treatments. Potato leaves from several plants (6 plants/ replicate) collected and kept in $-80^{\circ} \mathrm{C}$ until the time of analysis. Also, soil and water used in irrigation were sampled and analyzed for physicochemical properties as shown in Table 1.

Table 1. Physicochemical properties of soil and water of Sahl-Eltina

\begin{tabular}{|l|l|l|l|l|l|l|l|l|l|l|l|}
\hline \multirow{2}{*}{ Sample } & \multirow{2}{*}{$\mathbf{p H}$} & \multirow{2}{*}{$\begin{array}{l}\mathbf{E C} \\
\mathbf{d S m}\end{array}$} & $\mathrm{Na}^{+}$ & $\mathbf{K}^{+}$ & $\mathrm{Ca}^{+2}$ & $\mathbf{M g}^{+2}$ & $\mathbf{C O}_{3}^{-2}$ & $\mathbf{H C O}_{3}^{-}$ & $\mathbf{C l}^{-}$ & $\mathbf{S O}_{4}^{-2}$ \\
\cline { 4 - 11 } & & & \multicolumn{8}{|c|}{ m-equivalents /liter } \\
Soil & 8.38 & 1.27 & 7.20 & 0.50 & 2.73 & 2.23 & - & 2.16 & 5.8 & 4.7 \\
Water & 7.62 & 1.71 & 8.79 & 0.82 & 5.17 & 2.35 & 2.35 & 0.94 & 8.93 & 4.91 \\
\hline
\end{tabular}

Data represent the means of three replicates. 
At harvesting time, potato tubers collected when the soil was wet to easily pick it out. The tubers weighed, washed, sliced, dried and weighed again for tuber dry matter percentage Photosynthetic pigments were measured according to the methodology of Warren, (2008). Free proline and malondialdehyde (MDA) contents were determined spectrophotometrically according to the method of Zhang and Huang (2013).

\section{Experimental design and statistical analysis}

Cultivated area was divided into three main plots representing the applied water regimes and sub-plots containing the foliar application treatments. Treatments were represented in three replicates (twelve plants/replicate). Values of the recorded and measured traits were statistically analyzed as full factorial design in three replicates and subjected to analysis of variance (ANOVA) using IBM SPSS ${ }^{\circledR}$ Statistics 19 software package. Means were compared in CoStat version 6.400, CoHort Software using Duncan's multiple range test at $p \leq 0.05$ (Duncan, 1955).

\section{RESULTS AND DISCUSSION}

Effect of applied treatments under studied stress on photosynthetic pigments

Chlorophyll content usually decreases in plant exposed to environmental stresse (Ahmad et al 2007 and Saleem et al 2011). Rate of photosynthesis affected adversely due to inactivation of chlorophyll, an increase in transcripts encoding enzymes involved in chlorophyll degradation (chlorophyllase, pheophorbide a oxygenase) (Amirjani and Mahdiyeh, 2013). Non-enzymatic antioxidants particularly ascorbic acid scavenges ROS and restricts chlorophyll degradation under stress conditions (Ashraf, 2009). Also, Hemavathi et al (2009) demonstrated the over-expression of $D$ galacturonic acid reductase GalUR gene in potato lines enhanced endogenous (As) which contributed to mitigation to drought stress compared to untransformed lines.

Table (2), illustrates water deficit, ascorbate and their interaction. Data showed no significant differences among means of $\mathrm{Chl}$ (a) and (b) content. Meanwhile, ascorbate $(0.25 \mathrm{mM})$ showed the highest value compared with other concentration at both 4DI and 5DI water regimes. Results are in agree with Zonouri et al (2014) who found that, the use of ascorbate had no significant effect on $\mathrm{Chl} \mathrm{a}$ and $\mathrm{Chl} b$ under drought condition. However, $\mathrm{Naz}$ et al (2016) found that foliar application of ascorbic acid in cucumber enhanced chlorophyll (a) content with no change in chlorophyll (b) content under water stress.

In salicylate-treated group, water deficit significantly reduced $\mathrm{Chl} a$ and $\mathrm{b}$ content. These results are in harmony with Mafakheri et al (2010), Changhai et al (2010) and Shan et al (2012), they suggested that the decrease in Chl content under drought stress may be the result of pigment degradation and photo-oxidation. The main effect of salicylate treatment was not statistically significant, while Sa $(1.0 \mathrm{mM})$ slightly increased Chl a content by $11.85 \%$ compared to control. However, the water deficit-salicylate interaction showed that, the highest value was recorded by $\mathrm{Sa}(1.0 \mathrm{mM})$, at the control water regime $(0.935 \mathrm{mg} / \mathrm{g}$ f.w. $)$, and the same concentration $\mathrm{Sa}(1.0 \mathrm{mM})$ enhanced mean Chl a content at 4DI and 5DI, compared with control one and other concentrations. Results are in partial agreement with positive effects of salicylic acid on Chl a content in Brassica napus (Ghai et al 2002) and in barely (El-Tayeb 2005).

Similarly, effect of salicylate on Chl b was not associated with significant differences, while $\mathrm{Sa}$ $(1.0 \mathrm{mM})$ showed a slight increment of Chl b compared with control and other concentrations. Chlorophyll content is considered as an important indicator of plant productivity, because it is directly related to the photosynthetic rate of plants for biomass production (Wang and Huang, 2004)

The interactive effects between water deficit and salicylate treatment showed that, at control level, Sa (at 0.25, 0.5, and $1.0 \mathrm{mM}$ ) increased Chl b content by $10.75,7.95$ and $36.86 \%$, respectively, while at 4DI level, Chl b content increased by 18.7 and $14.2 \%$ respectively when Sa $(0.25$ and 1.0 $\mathrm{mM}$ ) were used,. These results agree with Arfan et al (2007) on wheat; Yildirim et al (2008) on cucumber.

Concerning silicate application, main effects of water deficit and silicate treatment showed no significant differences on both $\mathrm{Chl} a$ and $\mathrm{b}$ contents (Table 2). The interaction between water deficit and silicate treatment on $\mathrm{Chl}$ a showed that, different concentration of silicate shared the same rank under the studied water regimes, while application of silicate (100, 250 and $500 \mathrm{ppm})$ tended to enhance $\mathrm{Chl}$ a by $10.45,7.93$ and $6.71 \%$, respectively at 5DI water regime, compared to control one. 
Table 2. Chlorophyll $a$ and $b(\mu \mathrm{g} / \mathrm{g}$ f.w.) mean contents in potato leaves as affected by exogenous treatment of ascorbate $(0,0.25,0.5$, and $1.0 \mathrm{mM})$, salicylate $(0,0.25,0.5$ and $1.0 \mathrm{mM})$, and silicate $(0,100,250$ and 500 ppm) under water deficit regimes; i.e. three days interval (control) , four days interval (4DI), and five days interval (5DI) and their interaction.

\begin{tabular}{|c|c|c|c|c|c|}
\hline \multirow{2}{*}{$\begin{array}{c}\text { Exogenous } \\
\text { Treatment }\end{array}$} & \multirow{2}{*}{ Concentration } & \multicolumn{3}{|c|}{ Water regime } & \multirow[b]{2}{*}{ Mean } \\
\hline & & Control & 4DI & 5DI & \\
\hline & \multicolumn{5}{|c|}{ Chlorophyll a (mg/g f.w.) } \\
\hline \multirow{5}{*}{ Ascorbate } & $0.0 \mathrm{mM}$ & $0.761^{\mathrm{a}}$ & $0.738^{a}$ & $0.728^{a}$ & $0.742^{A}$ \\
\hline & $0.25 \mathrm{mM}$ & $0.669^{a}$ & $0.756^{a}$ & $0.704^{a}$ & $0.71^{\mathrm{A}}$ \\
\hline & $0.5 \mathrm{mM}$ & $0.686^{a}$ & $0.75^{\mathrm{a}}$ & $0.696^{a}$ & $0.711^{\mathrm{A}}$ \\
\hline & $1.0 \mathrm{mM}$ & $0.675^{a}$ & $0.667^{\mathrm{a}}$ & $0.667^{\mathrm{a}}$ & $0.67^{\mathrm{A}}$ \\
\hline & Mean & $0.698^{A}$ & $0.728^{A}$ & $0.699^{A}$ & \\
\hline \multirow{5}{*}{ Salicylate } & $0.0 \mathrm{mM}$ & $0.761^{\text {ab }}$ & $0.738^{a b}$ & $0.728^{\mathrm{ab}}$ & $0.742^{A}$ \\
\hline & $0.25 \mathrm{mM}$ & $0.808^{a b}$ & $0.79^{\mathrm{ab}}$ & $0.618^{b}$ & $0.738^{\mathrm{A}}$ \\
\hline & $0.5 \mathrm{mM}$ & $0.762^{a b}$ & $0.692^{b}$ & $0.698^{b}$ & $0.718^{\mathrm{A}}$ \\
\hline & $1.0 \mathrm{mM}$ & $0.935^{a}$ & $0.822^{a b}$ & $0.732^{a b}$ & $0.83^{\mathrm{A}}$ \\
\hline & Mean & $0.816^{A}$ & $0.761^{\mathrm{AB}}$ & $0.694^{\mathrm{B}}$ & \\
\hline \multirow{5}{*}{ Silicate } & $0.0 \mathrm{ppm}$ & $0.784^{\mathrm{a}}$ & $0.746^{\mathrm{a}}$ & $0.723^{a}$ & $0.751^{A}$ \\
\hline & 100 ppm & $0.796^{a}$ & $0.812^{a}$ & $0.798^{a}$ & $0.802^{A}$ \\
\hline & 250 ppm & $0.821^{\mathrm{a}}$ & $0.674^{a}$ & $0.78^{a}$ & $0.758^{\mathrm{A}}$ \\
\hline & 500 ppm & $0.663^{a}$ & $0.711^{\mathrm{a}}$ & $0.771^{\mathrm{a}}$ & $0.715^{\mathrm{A}}$ \\
\hline & Mean & $0.766^{\mathrm{A}}$ & $0.736^{\mathrm{A}}$ & $0.768^{A}$ & \\
\hline & \multicolumn{5}{|c|}{ Chlorophyll b (mg/g f.w) } \\
\hline \multirow{5}{*}{ Ascorbate } & $0.0 \mathrm{mM}$ & $0.476^{\mathrm{a}}$ & $0.446^{a}$ & $0.464^{\mathrm{a}}$ & $0.462^{A}$ \\
\hline & $0.25 \mathrm{mM}$ & $0.407^{\mathrm{a}}$ & $0.472^{a}$ & $0.452^{a}$ & $0.444^{\mathrm{A}}$ \\
\hline & $0.5 \mathrm{mM}$ & $0.427^{\mathrm{a}}$ & $0.488^{a}$ & $0.435^{\mathrm{a}}$ & $0.45^{\mathrm{A}}$ \\
\hline & $1.0 \mathrm{mM}$ & $0.439^{a}$ & $0.403^{a}$ & $0.404^{a}$ & $0.415^{A}$ \\
\hline & Mean & $0.437^{\mathrm{A}}$ & $0.452^{A}$ & $0.439^{\mathrm{A}}$ & \\
\hline \multirow{5}{*}{ Salicylate } & $0.0 \mathrm{mM}$ & $0.476^{\mathrm{ab}}$ & $0.446^{b}$ & $0.464^{b}$ & $0.462^{A}$ \\
\hline & $0.25 \mathrm{mM}$ & $0.527^{\mathrm{ab}}$ & $0.529^{a b}$ & $0.398^{b}$ & $0.485^{\mathrm{A}}$ \\
\hline & $0.5 \mathrm{mM}$ & $0.514^{\mathrm{ab}}$ & $0.447^{b}$ & $0.457^{b}$ & $0.473^{\mathrm{A}}$ \\
\hline & $1.0 \mathrm{mM}$ & $0.651^{a}$ & $0.509^{a b}$ & $0.45^{b}$ & $0.537^{A}$ \\
\hline & Mean & $0.542^{A}$ & $0.483^{\mathrm{AB}}$ & $0.442^{B}$ & \\
\hline \multirow{5}{*}{ Silicate } & 0.0 ppm & $0.519^{a}$ & $0.393^{\mathrm{a}}$ & $0.45^{\mathrm{a}}$ & $0.454^{A}$ \\
\hline & 100 ppm & $0.511^{a}$ & $0.514^{a}$ & $0.539^{a}$ & $0.521^{A}$ \\
\hline & 250 ppm & $0.536^{a}$ & $0.373^{a}$ & $0.532^{a}$ & $0.481^{\mathrm{A}}$ \\
\hline & 500 ppm & $0.417^{\mathrm{a}}$ & $0.455^{a}$ & $0.498^{a}$ & $0.457^{\mathrm{A}}$ \\
\hline & Mean & $0.496^{\mathrm{A}}$ & $0.434^{A}$ & $0.505^{A}$ & \\
\hline
\end{tabular}

Data represent the means of three replicates. Values followed by different letters in a column or in Mean row are significantly different, while the same letters are not different at $p \leq 0.05$ by Duncan's multiple range test

The interaction between water deficit and silicate treatment on $\mathrm{Chl} b$ showed a same trend. However, silicate (100 and 500 ppm treatments) improved Chl b by 30.85 and $15.97 \%$ respectively compared to control with 4DI water regime. Meanwhile, at 5DI water regime, application of silicate (100, 250 and 500 ppm) improved Chl b by 19.58 ,
18.15 and $10.64 \%$ respectively compared to control one.

Silicon increased the level of chlorophyll (a) under the water-deficient tomato cultivars, indicating the synthesis of new pigments and the maintenance of previously existing chlorophyll (a) (Silva et al 2012). 

stress conditions

\section{Effect of applied treatments under studied stress on Carotenoids}

Carotenoids have essential role in photosynthesis and photo-protection, besides their structural roles, they are well-known for their nonenzymatic antioxidant activity by quenching free radicals, inhibiting lipid peroxidation, and stabilizing membranes (Cruz de Carvalho, 2008 and Farooq et al 2009), in addition to their nutritional value for potato plant (Payyavula, 2012). In our study, regarding ascorbate-treated group, main effect of water deficit and ascorbate treatment on carotenoids content illustrated in Table (3). Data cleared no markedly changes. However, carotenoids content tended to increase with increasing water stress.

Table 3. Carotenoids ( $\mu \mathrm{g} / \mathrm{g}$ f.w.) mean contents in potato leaves as affected by exogenous treatment of ascorbate $(0,0.25,0.5$, and $1.0 \mathrm{mM})$, salicylate $(0,0.25,0.5$ and $1.0 \mathrm{mM})$, and silicate $(0$, 100,250 and 500ppm) under water deficit regimes; i.e. three days interval (control), four days interval (4DI), and five days interval (5DI) and their interaction.

\begin{tabular}{|c|c|c|c|c|c|}
\hline \multirow{2}{*}{ Exogenous application } & \multirow{2}{*}{ Concentration } & \multicolumn{4}{|c|}{ Water regime } \\
\hline & & Control & 4DI & 5DI & Mean \\
\hline \multirow{5}{*}{ Ascorbate } & $0.0 \mathrm{mM}$ & $66.534^{\mathrm{ab}}$ & $53.688^{\mathrm{ab}}$ & $58.434^{\mathrm{ab}}$ & $59.552^{A}$ \\
\hline & $0.25 \mathrm{mM}$ & $48.074^{\mathrm{ab}}$ & $72.372^{a}$ & $58.848^{a b}$ & $59.764^{A}$ \\
\hline & $0.5 \mathrm{mM}$ & $39.302^{b}$ & $55.846^{\mathrm{ab}}$ & $50.619^{a b}$ & $48.589^{A}$ \\
\hline & $1.0 \mathrm{mM}$ & $40.021^{b}$ & $46.456^{\mathrm{ab}}$ & $46.625^{\mathrm{ab}}$ & $44.367^{A}$ \\
\hline & Mean & $48.483^{A}$ & $57.090^{A}$ & $53.631^{A}$ & \\
\hline \multirow{5}{*}{ Salicylate } & $0.0 \mathrm{mM}$ & $66.534^{a}$ & $53.688^{\mathrm{abc}}$ & $58.434^{\mathrm{ab}}$ & $59.552^{A}$ \\
\hline & $0.25 \mathrm{mM}$ & $53.797^{\mathrm{abc}}$ & $30.329^{c}$ & $33.833^{\mathrm{bc}}$ & $39.320^{\mathrm{B}}$ \\
\hline & $0.5 \mathrm{mM}$ & $46.261^{a b c}$ & $62.841^{\mathrm{a}}$ & $60.405^{\mathrm{ab}}$ & $56.502^{A}$ \\
\hline & $1.0 \mathrm{mM}$ & $57.984^{\mathrm{ab}}$ & $29.938^{c}$ & $48.372^{\mathrm{abc}}$ & $45.431^{\mathrm{AB}}$ \\
\hline & Mean & $56.144^{A}$ & $44.199^{A}$ & $50.261^{A}$ & \\
\hline \multirow{5}{*}{ Silicate } & 0.0 ppm & $60.663^{\mathrm{bc}}$ & $56.224^{\mathrm{C}}$ & $69.233^{\mathrm{abc}}$ & $62.040^{A}$ \\
\hline & 100 ppm & $75.921^{a b}$ & $60.584^{\mathrm{bc}}$ & $66.435^{\mathrm{abc}}$ & $67.647^{A}$ \\
\hline & 250 ppm & $55.529^{c}$ & $53.889^{c}$ & $85.131^{a}$ & $64.850^{A}$ \\
\hline & 500 ppm & $53.054^{c}$ & $62.982^{b c}$ & $55.923^{c}$ & $57.320^{A}$ \\
\hline & Mean & $61.292^{A B}$ & $58.420^{\mathrm{B}}$ & $69.180^{A}$ & \\
\hline
\end{tabular}

Data represent the means of three replicates. Values followed by different letters in a column or in Mean row are significantly different, while the same letters are not different at $p \leq 0.05$ by Duncan's multiple range test.

The interaction between water deficit and ascorbate treatment showed the highest carotenoids content by $72.37 \mathrm{mg} / \mathrm{g}$ (f.w.) at As $(0.25 \mathrm{mM})$ by $34.8 \%$ increment, compared to control, at $4 \mathrm{DI}$ water level.

Hanci and Cebeci (2014) reported that, at drought conditions, carotenoids content in two onion cultivars were decreased and the reduction may be due to over production and accumulation of ROS under severe drought stress.

Concerning salicylate -treated group, the effect of water reduction on carotenoids did not recorded significant differences among the levels of water regime. However, the effect of salicylate was significant regarding this trait. The interaction between salicylate treatment and water deficit resulted in, at control water regime, all salicylate concentration tended to reduce the carotenoids content but with no significant change. At 4DI water regime, $\mathrm{Sa}(1.0 \mathrm{mM})$ recorded the lowest carotenoids content $(29.93 \mathrm{mg} / \mathrm{g}$ f.w.), however Sa (0.5 mM) recorded the highest carotenoids content $(62.84$ $\mathrm{mg} / \mathrm{g}$ f.w.). Similarly, Sa $(0.5 \mathrm{mM})$ recorded the highest carotenoids content $(60.4 \mathrm{mg} / \mathrm{g} \mathrm{f.w}$.) at 5DI water level. Salycilic acid applied in suitable concentrations may induce the synthesis of protective compounds such as carotenoids which improves the anti-oxidative capacity and temporarily lower the level of oxidative stress in plants, (Hayat and Ahmed 2007).

In silicon-treated group, effect of water deficit on carotenoids content showed significant differences by increasing carotenoids content at 5DI water regime, compared with 4DI water regime. An increment in carotenoids content has been reported in many plants as a result of drought stress, (Ghobadi et al 2013 and Rodríguez-Pérez et al 2017).

The effect of interaction between water deficit and silicate treatment showed that, at control level 
of water regime, Si (100 ppm) increased carotenoids content by $25.15 \%$ compared with control one. At 4DI level, Si (100 and 500 ppm) increased carotenoids content by 7.75 and $12.02 \%$, respectively. Whereas Si (250 ppm) recorded the highest value by increasing carotenoids content by $22.96 \%$ at 5DI water level. This results are in a harmony and agree with (Maghsoudi et al 2016) who stated that, silicon supplementation induced enhancement in carotenoids content in wheat plants endangered drought stress

\section{Effect of applied treatments under studied stress on free proline}

Proline (Pro) is one of the most important osmolyte, plays a vital role that plants operate for survival under abiotic stress. Pro detoxifies excess ROS, adjusts cellular osmotic balance, protects biological membranes, and stabilizes enzymes/proteins (Iqbal et al 2014). In addition proline synthesis initiates the generation of $\mathrm{NADP}^{+}$, which acts as the backbone for ribose 5-phosphate required for the purines synthesis, and proline catabolism yields the reduced electron carriers, which provide energy for the numbers of biochemical reaction such as nitrogen fixation (Kim and Nam, 2013).

The results in Fig. (1) show that, free proline content increased significantly in response to water deficit. The results are in agree with Mafakheri et al (2010) who stated that, proline content increased significantly in response to drought.

Accumulation of large quantities of proline is an adaptive response of plants to abiotic stress (Ali et al 1999). However, high proline content in leaves of Andigena potato was related to susceptibility to water stress (Vasquez-Robinet et al 2008).

In case of ascorbate treated group (Fig.1a), ascorbate showed non-significant effect on proline content. The interaction between ascorbate treatment and water deficit represented that, at control water regime, as at $0.25,0.5$, and $1.0 \mathrm{mM}$ increased proline content compared to control. At 4DI water level, effect of ascorbate concentration was almost very close except in case of As $(0.5$ $\mathrm{mM}$ ), which decreased the content of proline compared to control.

At $5 \mathrm{D}$ water level, As at $(0.25,0.5$, and $1.0 \mathrm{mM})$ led to reduction of the mean free proline content compared to control.

Regarding salicylate application (Fig. 1b), the main effect of salicylate treatment showed that, Sa ( 0.5 and $1.0 \mathrm{mM}$ ) recorded significant reduction in proline content.
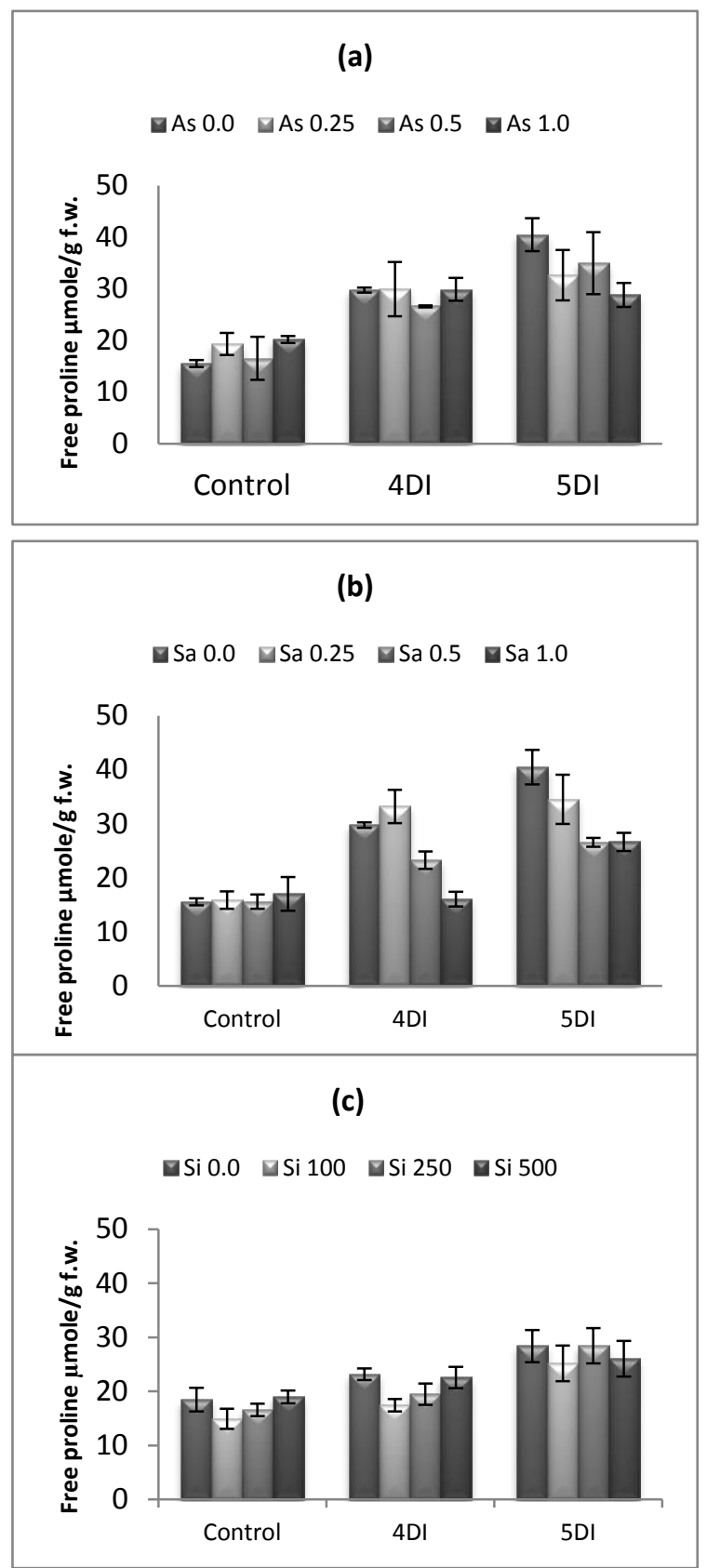

Fig. 1. Free proline content ( $\mu$ mole/g f.w.) in leaves of potato (cv. Spunta) as affected by (a) ascorbate $(0,0.25,0.5$, and $1.0 \mathrm{mM})$, (b) salicylate $(0,0.25,0.5$ and $1.0 \mathrm{mM})$, and (c) silicate $(0,100,250$ and 500ppm) and water deficit; control; three days interval, four days interval (4DI), and five days interval (5DI).

The interaction between salicylate treatment and water deficit shows that, at control water regime, all salicylate concentration showed the same trend on proline content. 
At 4DI level, Sa $(0.25 \mathrm{mM})$ increased proline content, but $\mathrm{Sa}(0.5$ and $1.0 \mathrm{mM})$ decreased proline content compared with control.

At 5DI level, Sa at $(0.25,0.5$ and $1.0 \mathrm{mM})$ decreased proline content compared with control.

Salicylic acid is a plant regulator that appears to be involved in the regulation of proline metabolism (Misra and Saxena 2009).Our data are in agreement with many studies, where Khan et al (2013) found that, Sa $(0.5 \mathrm{mM})$ increased proline content in wheat plant endangered heat stress. Also, in mustard plant exposed to drought stress, higher proline content was attributed to increased $\mathrm{N}$ and $\mathrm{S}$ assimilation and increased synthesis of proline synthesizing enzyme which lowers the oxidative stress in mustard (Nazar et al 2015). Concerning application with silicate (Fig. 1C), silicate concentrations (100, 250 and 500 ppm) showed reduction in proline content compared with control.

The interaction between silicate treatment and water deficit shows that, at control level of water regime, Si (100 and $250 \mathrm{ppm}$ ) reduced free proline compared with its control.

At 4DI water regime, Si (100, 250 and 500 $\mathrm{ppm})$ reduced free proline content compared with control. Silicate (100 and $500 \mathrm{ppm}$ ), at 5DI reduced proline content by 11.22 and $8.23 \%$, respectively compared to control. Our result agree with Gunes et al (2008) who observed that, silicon application reduced proline level, indicating that $\mathrm{Si}$ reduces stress levels because proline is considered a biochemical indicator of stress and an osmotic regulator.

Vasquez-Robinet et al (2008) found that response of the known osmolytes including proline to drought appeared not to be correlated with relative resistance and/or the ability to recover, but rather with the degree of stress experienced by different genotypes (Fig.1).

\section{Effect of applied treatments under studied stress on Malondialdehyde (MDA):}

The data in (Fig. 2a) show that, plants exposed to water deficit significantly revealed high accumulation in MDA content compared with control plants, while ascorbate treatment was not associated with marked differences in MDA content.

The effect of interaction between ascorbate treatment and water deficit showed that ascorbate promoted reduction in MDA content in case of As 1.0 by $16.9 \%$, and As 0.25 by $29.24 \%$, under 4DI and $5 \mathrm{DI}$ water regime respectively.

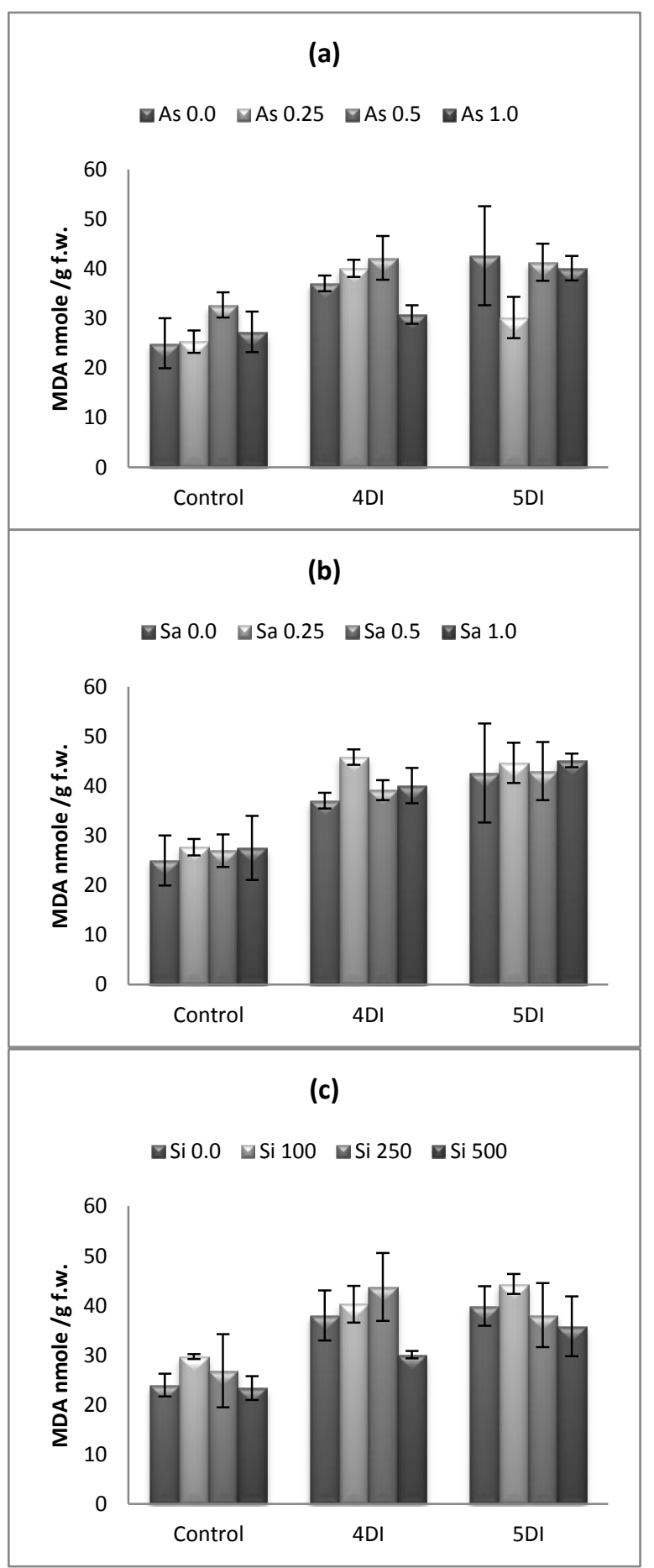

Fig.2 Malonyladialdehide (MDA) content (nmole/g f.w.) in leaves of potato (cv. Spunta) as affected by (a) ascorbate $(0,0.25,0.5$, and $1.0 \mathrm{mM})$, (b) salicylate $(0,0.25,0.5$ and $1.0 \mathrm{mM})$, and (c) silicate $(0,100,250$ and 500ppm) and water deficit; control; three days interval, four days interval (4DI), and five days interval (5DI). 
Concerning application with salicylate (Fig. 2b), salicylate treatment did not show significant effect on MDA content. The interaction of water deficit and salicylate treatment is presented in Fig. (2b). The results show that the increment in MDA content with water deficit was not affected significantly by application of salicylate, however, Sa (0.25 mM) increased MDA content compared with control one. Salicylic acid (0.5 mM)-supplemented T. aestivum exposed to drought showed low membrane lipid oxidation Kang et al (2012), which disagrees with our results.

Effect of silicate treatment shown in Fig. (2c) illustrates significant differences. Si (100 ppm) recorded the highest value, while the lowest one recorded by Si (500 ppm) which reduced MDA content by $12.36 \%$. It could be concluded that, the interaction effect between water deficit and silicate treatment in different concentration of silicate treatments showed similar effect at control, 4DI and 5DI water regime, whereas Si 500 ppm slightly decreased MDA content by 2.48, 20.84 and $10.21 \%$, respectively under the studied water regimes (Fig. 2).

\section{Effect of applied treatments under studied stress on plant dry matter}

The results presented in Table (4) show the means of plant dry matter percentage as affected by application of $\mathrm{As}$, $\mathrm{Sa}$, and $\mathrm{Si}$ concentrations under water deficit regimes.

Data clearly indicate that, exposure of potato plants to water deficit significantly decreased plant dry matter.

Ascorbate increment did not show significant differences on plant dry matter percentage. However, the interaction between ascorbate treatment and water deficit revealed the highest dry matter percentage with application of As $(0.5 \mathrm{mM})$ under control water regime, and the lowest percentage was observed with application of As $(0.5 \mathrm{mM})$, under 5DI water regime.

The data exhibited that, salicylate concentrations showed inconsistent effect on plant dry matter percentage. However, the interaction of salicylate treatment and water deficit on plant dry matter showed that, at control water regime, Sa (0.5 and $0.1 \mathrm{mM}$ ) improved plant dry matter by 17.83 and $10.05 \%$, respectively. At 4DI water regime, all salicylate concentration shared the same rank except for Sa $(0.5 \mathrm{mM})$, which reduced the plant dry mat- ter significantly compared to control one. At 5DI water regime, $\mathrm{Sa}(0.25 \mathrm{mM})$ significantly reduced plant dry matter compared to control. However, the other concentrations showed the same trend. The obtained results agree with the findings of Saruhan et al (2012), who found that Sa $(1.0 \mu \mathrm{M})$ increased dry weight, and strengthened antioxidant defense system in drought-tolerant $Z$. mays cultivar to a great extent vs. drought-sensitive cultivar.

Effect of drought stress of three Andean potato cultivars showed no significant differences in yield and growth parameters between well watered and drought stressed cultivars (Rodríguez-Pérez et al 2017).

Silicate levels affected plant dry matter significantly, and Si (250 ppm) exceeded other concentration significantly increased plant dry matter by $18.15 \%$. Meanwhile, the interaction effect between water deficit and silicate effects revealed that, $\mathrm{Si}$ (250 ppm) increased plant dry matter percentage by $10.51 \%$. At 4DI water regime, Si (100, 250, 500 ppm) amplified plant dry matter by 25.52, 25.36 and $10.89 \%$, respectively compared with control. In addition, 5DI water regime, Si (250 ppm) increased plant dry matter by $20.61 \%$ over the control.

\section{Effect of applied treatments under studied stress on tuber dry matter}

Tuber dry matter percentage represents the accumulated photosynthates in potato tubers which eventually constitute the yield. Means of the tuber dry matter are shown in Table (5), as affected by $\mathrm{As}, \mathrm{Sa}$, and $\mathrm{Si}$ concentrations and water deficit regimes.

Applied water deficit regimes reduced tuber dry matter percentage with marked effect only in the As-treated group.

Ascorbate increasing concentrations, along with the interaction of water deficit regimes and ascorbate showed no significant differences among tuber dry matter percentage.

Regarding salicylate main effect, increasing Sa concentration showed similar effects on tuber dry matter percentage. Effect of interaction between salicylate and water deficit noted that, Sa (1.0 mM) recorded the highest value $20.761 \%$ under control water regime, almost all salicylate concentrations tended to enhance tuber dry matter percentage under all water regimes. 
Table 4. Plant dry matter percentage as affected by exogenous treatment of ascorbate $(0,0.25$, 0.5 , and $1.0 \mathrm{mM})$, salicylate $(0,0.25,0.5$ and $1.0 \mathrm{mM})$, and silicate $(0,100,250$ and $500 \mathrm{ppm})$ under water deficit regimes; i.e. three days interval (control), four days interval (4DI), and five days interval (5DI) and their interaction.

\begin{tabular}{|c|c|c|c|c|c|}
\hline \multirow{2}{*}{$\begin{array}{l}\text { Exogenous } \\
\text { application }\end{array}$} & \multirow{2}{*}{ concentration } & \multicolumn{2}{|c|}{ Water regime } & \multirow[b]{2}{*}{ 5DI } & \multirow[b]{2}{*}{ Mean } \\
\hline & & Control & 4DI & & \\
\hline \multirow{5}{*}{ Ascorbate } & $0.0 \mathrm{mM}$ & $11.871^{\mathrm{bcd}}$ & $12.132^{\mathrm{bcd}}$ & $10.906^{d}$ & $11.636^{\mathrm{A}}$ \\
\hline & $0.25 \mathrm{mM}$ & $12.474^{b c}$ & $11.320^{\mathrm{cd}}$ & $11.508^{\mathrm{bcd}}$ & $11.767^{\mathrm{A}}$ \\
\hline & $0.5 \mathrm{mM}$ & $14.215^{a}$ & $11.935^{\mathrm{bcd}}$ & $9.597^{\mathrm{e}}$ & $11.915^{\mathrm{A}}$ \\
\hline & $1.0 \mathrm{mM}$ & $10.905^{d}$ & $12.838^{b}$ & $11.667^{\mathrm{bcd}}$ & $11.803^{A}$ \\
\hline & Mean & $12.366^{\mathrm{A}}$ & $12.056^{\mathrm{A}}$ & $10.920^{B}$ & \\
\hline \multirow{5}{*}{ Salicylate } & $0.0 \mathrm{mM}$ & $11.871^{\mathrm{bcd}}$ & $12.132^{b c}$ & $10.906^{\text {cd }}$ & $11.636^{A}$ \\
\hline & $0.25 \mathrm{mM}$ & $11.219^{\mathrm{cd}}$ & $11.047^{c d}$ & $8.645^{\mathrm{e}}$ & $10.304^{A}$ \\
\hline & $0.5 \mathrm{mM}$ & $13.988^{a}$ & $10.527^{d}$ & $11.210^{\mathrm{cd}}$ & $11.908^{A}$ \\
\hline & $1.0 \mathrm{mM}$ & $13.064^{\mathrm{ab}}$ & $10.972^{c d}$ & $10.570^{d}$ & $11.535^{\mathrm{A}}$ \\
\hline & Mean & $12.536^{\mathrm{A}}$ & $11.170^{\mathrm{B}}$ & $10.333^{c}$ & \\
\hline \multirow{5}{*}{ Silicate } & 0.0 ppm & $13.482^{a b}$ & $10.788^{b c}$ & $10.212^{c d}$ & $11.494^{\mathrm{B}}$ \\
\hline & 100 ppm & $11.044^{c d}$ & $13.541^{a b}$ & $9.586^{d}$ & $11.390^{B}$ \\
\hline & 250 ppm & $14.900^{a}$ & $13.524^{a b}$ & $12.317^{b c}$ & $13.580^{A}$ \\
\hline & 500 ppm & $11.936^{\mathrm{bc}}$ & $11.963^{b c}$ & $9.580^{d}$ & $11.160^{B}$ \\
\hline & Mean & $12.840^{A}$ & $12.454^{A}$ & $10.424^{B}$ & \\
\hline
\end{tabular}

Data represent the means of three replicates. Values followed by different letters in a column or in Mean row are significantly different, while the same letters are not different at $p \leq 0.05$ by Duncan's multiple range test.

Table 5. Tuber dry matter percentage as affected by exogenous treatment of ascorbate $(0,0.25,0.5$, and $1.0 \mathrm{mM})$, salicylate $(0,0.25,0.5$ and $1.0 \mathrm{mM})$, and silicate $(0,100,250$ and $500 \mathrm{ppm})$ under water deficit regimes; i.e. three days interval (control), four days interval (4DI), and five days interval (5DI) and their interaction.

\begin{tabular}{|c|c|c|c|c|c|}
\hline \multirow{2}{*}{$\begin{array}{l}\text { Exogenous } \\
\text { application }\end{array}$} & \multirow{2}{*}{ concentration } & \multicolumn{2}{|c|}{ Water regime } & \multirow[b]{2}{*}{ 5DI } & \multirow[b]{2}{*}{ Mean } \\
\hline & & Control & 4DI & & \\
\hline \multirow{5}{*}{ Ascorbate } & $0.0 \mathrm{mM}$ & $19.685^{\mathrm{a}}$ & $20.087^{a}$ & $19.030^{a}$ & $19.601^{A}$ \\
\hline & $0.25 \mathrm{mM}$ & $19.452^{a}$ & $20.057^{a}$ & $19.026^{a}$ & $19.512^{A}$ \\
\hline & $0.5 \mathrm{mM}$ & $19.678^{a}$ & $19.857^{a}$ & $19.200^{\mathrm{a}}$ & $19.578^{A}$ \\
\hline & $1.0 \mathrm{mM}$ & $19.935^{a}$ & $20.011^{a}$ & $19.301^{\mathrm{a}}$ & $19.749^{A}$ \\
\hline & Mean & $19.687^{A B}$ & $20.003^{A}$ & $19.139^{B}$ & \\
\hline \multirow{5}{*}{ Salicylate } & $0.0 \mathrm{mM}$ & $19.685^{\mathrm{ab}}$ & $20.087^{\mathrm{ab}}$ & $19.030^{b}$ & $19.601^{\mathrm{A}}$ \\
\hline & $0.25 \mathrm{mM}$ & $20.296^{\text {ab }}$ & $20.439^{a b}$ & $19.875^{\mathrm{ab}}$ & $20.203^{A}$ \\
\hline & $0.5 \mathrm{mM}$ & $20.684^{a b}$ & $19.968^{a b}$ & $19.845^{\mathrm{ab}}$ & $20.166^{A}$ \\
\hline & $1.0 \mathrm{mM}$ & $20.761^{a}$ & $20.069^{a b}$ & $19.810^{\text {ab }}$ & $20.213^{A}$ \\
\hline & Mean & $20.356^{A}$ & $20.141^{A}$ & $19.640^{A}$ & \\
\hline \multirow{5}{*}{ Silicate } & 0.0 ppm & $20.317^{a}$ & $19.317^{a}$ & $19.496^{\mathrm{a}}$ & $19.710^{A}$ \\
\hline & 100 ppm & $19.987^{\mathrm{a}}$ & $19.348^{a}$ & $19.338^{a}$ & $19.558^{A}$ \\
\hline & 250 ppm & $19.750^{a}$ & $18.879^{a}$ & $19.177^{\mathrm{a}}$ & $19.269^{A}$ \\
\hline & 500 ppm & $19.835^{a}$ & $19.350^{a}$ & $18.725^{a}$ & $19.303^{A}$ \\
\hline & Mean & $19.972^{A}$ & $19.223^{A}$ & $19.184^{A}$ & \\
\hline
\end{tabular}

Data represent the means of three replicates. Values followed by different letters in a column or in Mean row are significantly different, while the same letters are not different at $p \leq 0.05$ by Duncan's multiple range test. 
On the subject of Si-treated plants, application with silicate under water deficit conditions showed no marked differences on tuber dry matter percentages.

\section{Effect of applied treatments under studied stress on tuber yield.}

The data, represented in Fig. (3), show that, tuber yield decreased significantly in relation to water deficit. As known, potato is quite sensitive to water deficit (Loon, 1981). This sensitivity can be attributed to its small and shallow root system, which makes the plant ineffective for absorbing water (Gregory and Simmonds, 1992). Short water deficit periods may result in reduced tuber growth, yield, and quality (Costa et al 1997).

The effect of studied concentrations of As, illustrated in Fig. (3a), shows that As improved tuber yield by $46.89,15.62$ and $5 \%$ at As $(0.25,0.5$ and $1.0 \mathrm{mM}$ ), respectively, and this improvement was related to the low concentration of ascorbate rather than the higher ones.

The interaction between water deficit and ascorbate showed that ascorbate at $0.25 \mathrm{mM}$ improved tuber yield by $50.32 \%, 25.79 \%$ and $73.38 \%$ respectively under control, 4DI and 5DI water levels,. Ascorbate $(0.5 \mathrm{mM})$ enhanced plant tuber yield by 19.95 and $50.44 \%$, under control and 5DI water regimes. However, the higher concentration of ascorbate (As $1.0 \mathrm{mM}$ ) enhanced plant tuber yield by 6.7 and $24.46 \%$ under $4 \mathrm{DI}$ and $5 \mathrm{DI}$, compared with control one.

Mukhtar et al (2016) observed that, application of As at 75 and $150 \mathrm{mg} \mathrm{L}^{-1}$ improving plant growth due to As-induced decrease in $\mathrm{H}_{2} \mathrm{O}_{2}$ contents and membrane permeability in addition to increase in chlorophyll, proline, glycinebetaine, potassium and phosphorus contents, under water-deficit conditions in cauliflower plants.

Effect of salicylate concentrations, in Fig. (3b), shows that, salicylate levels were not associated with clear differences on plant tuber yield means.

The interaction between water deficit and salicylate presented that, main effect of salicylate on tuber yield was fluctuating between increment and decrement at both control and 4DI water level. But it is obvious that, all salicylate concentration $(0.25$, 0.5 and $1.0 \mathrm{mM}$ ) improved tuber yield at 5DI water regime by $65.61,21.8$ and $33.33 \%$ respectively, compared to its control.

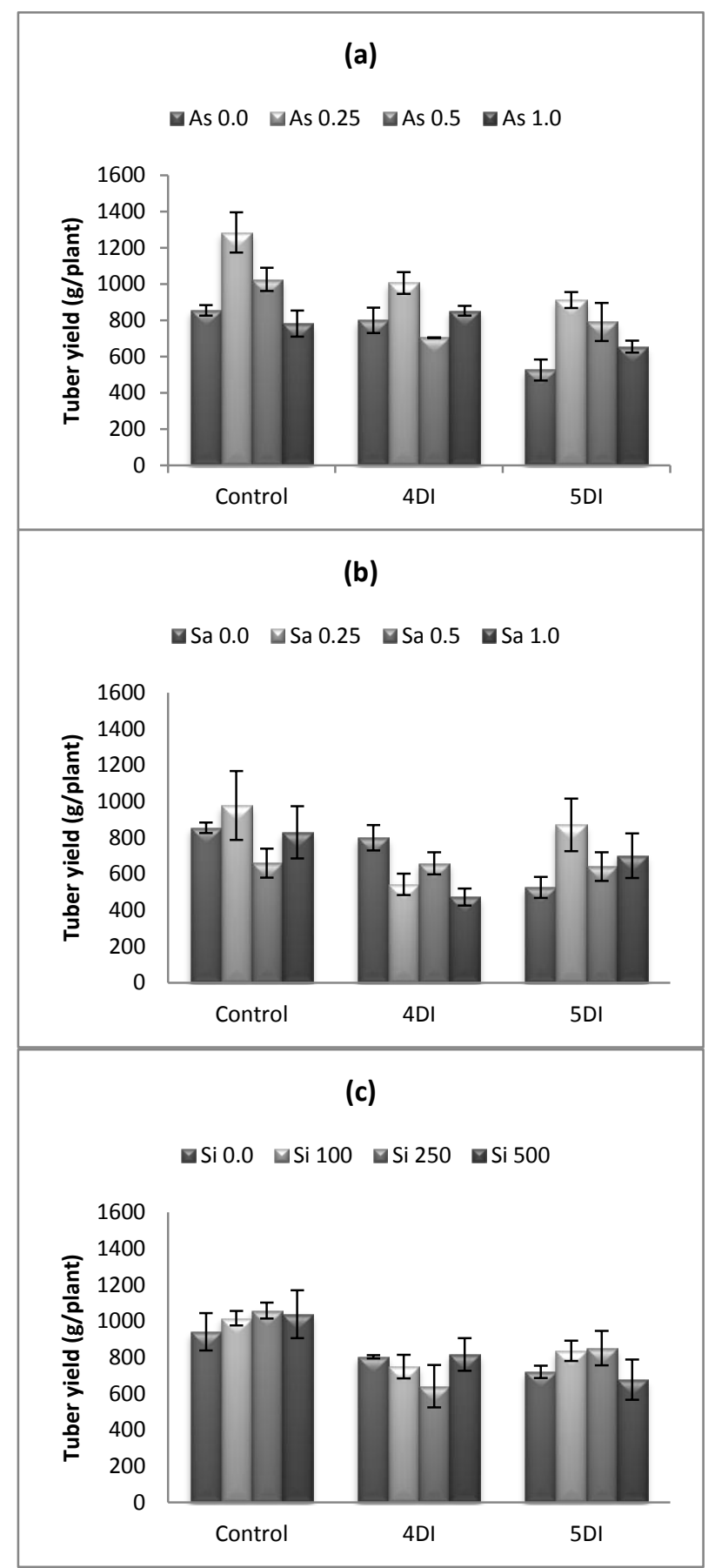

Fig.3 Tuber yield (g/plant) of potato (cv. Spunta) as affected by (a) ascorbate $(0,0.25,0.5$, and $1.0 \mathrm{mM})$, (b) salicylate $(0,0.25,0.5$ and $1.0 \mathrm{mM})$, and (c) silicate $(0,100,250$ and 500ppm) and water deficit; control; three days interval, four days interval (4DI), and five days interval $(5 \mathrm{DI})$. 
It could be concluded that, the increment of tuber yield by salicylate application was in parallel with reduction in free proline content.

Foliar application of (Sa) is involved in stomatal regulation thereby controlling photosynthetic rate (Khan et al 2003). Activity of Rubisco, and activity of some important enzymes are some possible roles assigned to SA-induced stress tolerance. (Hayat and Ahmed, 2007).

In silicate treated group, the data presented in (Fig. 3c) show that, silicate concentrations illustrate no significant differences on tuber yield.

The interaction between water deficit and silicate treatment show that, Si at 100, 250 and 500 ppm slightly increased plant tuber yield by 7.9 , 12.5 and $10.4 \%$, respectively

, under the control of water regime.

Under 4DI water regime, all silicate concentrations had the same rank, while at 5DI water level, Si (100 and 250 ppm) increased the yield by 16.15 and $18.15 \%$, respectively (Fig.3).

$\mathrm{Si}$ treatment alleviated the reduction in yield caused by water stress in roselle plant; this might be attributed to the effect of $\mathrm{Si}$ on plant growth improvement and enhancement of water status under stress (Maghsoudi et al 2016). Also, Si affects potato tuber skin by increasing suberization and by upregulating suberin-associated 3-ketoacylCoA synthase (which is participated in suberin deposition). Si was also shown to decrease the age-dependent changes in the skin cell area, via a structural stabilization of the cell wall, thereby delaying senescence of the tuber skin (Vulavala et al 2015).

\section{CONCLUSION}

It could be concluded that, ascorbate (As) under water deficit has a superior effect at $0.25 \mathrm{mM}$, also salicylate treatments reduced free proline with a slight increment in tuber dry matter and tuber yield. Silicate treatment alleviated water stress by improving carotenoids content, plant dry matter and reducing both free proline and MDA contents, which attributes enhancement in tuber yield under water deficit.

Generally, lower concentrations of As, Sa and $\mathrm{Si}$ showed their benefits under higher water stress regimes.

\section{REFERENCES}

Ahmad, M.S.A., Khan, F.J. and Ashraf, M., 2007. Iso-osmotic effect of $\mathrm{NaCl}$ and $P E G$ on growth, cations and free proline accumulation in callus tissue of two indica rice (Oryza sativa L.) genotypes. Plant Growth Regul., 53, 53-63.

Ali, G., Srivastava, P.S. and Iqbal, M., 1999. Proline accumulation, protein pattern and photosynthesis in Bacopa monnieri regenerates grown under $\mathrm{NaCl}$ stress. Biol Plant, 42, 89-95.

Amirjani, M.R. and Mahdiyeh, M. 2013. Antioxidative and biochemical responses of wheat to drought stress. J. Agric. Biol. Sci., 8(4), 291301.

Arfan, M., Athar, H.R. and Ashraf, M., 2007. Does exogenous application of salicylic acid through the rooting medium modulate growth and photosynthetic capacity in two differen-tly adapted spring wheat cultivars under salt stress? J. Plant. Physiol., 164, 685-694.

Ashraf, M., 2009. Biotechnological approach of improving plant salt tolerance using antioxidants as markers. Biotechnol. Adv., 27, 84-93.

Athar, H., Khan, A. and Ashraf, M., 2008. Exogenously applied ascorbic acid alleviates salt induced oxidative stress in wheat. Environ. Exp. Bot., 63, 224-231.

Changhai, S., Baodi, D., Yunzhou, Q., Yuxin, L., Lei, S., Mengyu, L. and Haipei, L.; 2010. Physiological regulation of high transpiration efficiency in winter wheat under drought conditions. Plant Soil Environ., 56(7), 340-347.

Costa, L.D., Vedove, G.D., Gianquintoi, G., Gi ovanardi, R. and Peressotti. A., 1997. Yield, water use efficiency, and nitrogen uptake in potato: Influence of drought stress. Potato Res., 40, $19-34$.

Cruz de Carvalho, M.H., 2008. Drought stress and reactive oxygen species: production, scavenging and signaling. Plant Signal. Behav., 3, 156165.

Duncan, D.B., 1955. "Multiple range and multiple F tests". Biometrics., 11, 1-42.

El-Tayeb, M.A., 2005. Response of barley grains to the interactive effect of salinity and salicylic acid. Plant Growth Regulation, 45, 215-224.

Farooq, M.; Wahid, A., Kobayashi, N., Fujita, D. and Basra, S.M., 2009. Plant drought stress: effects, mechanisms, and management. Agron. Sustain. Dev., 29, 185-212.

Foyer, C.H. and Noctor, G., 2011. Ascorbate and glutathione: the heart of the redox hub. Plant Physiol., 155, 2-18.

Ghai, N., Setia, R.C. and Setia, N., 2002. Effect of paclobutrazol and salicylic acid on chlorophyll content, hill activity and yield components in Brassica napus L. (cv. GSL-1). Phytomorphology, 52, 83-87. 
Ghobadi, M.S., Taherabadi, M.E., Mohammadi, G. and Jalali-Honarmand, S., 2013. Antioxidant capacity. Photosynthetic characteristics and water relations of sunflower (He-lianthus annuus L.) cultivars in response to drought stress. Ind. Crop. Prod., 50, 29-38.

Gregory, P.J., and Simmonds, L.P., 1992. Water relations and growth of potatoes. $\left(2^{\text {nd }} E d\right)$. In Harris P.M. (ed.) The potato crop: The scientific basis for improvement. Chapman and Hall, London, UK, pp. 214-246..

Gunes, A., Pilbeam, D., Inal, A. and Coban, S., 2008. Influence of silicon on sunflower cultivars under drought stress, I: Growth, antioxidant mechanisms and lipid peroxidation. Soil Science \& Plant Nutrition, 39, 1885-1903.

Hanci, F. and Cebeci, E., 2014. Investigation of proline, chlorophyll and carotenoids changes under drought stress in some onion (Allium cepa L.) cultivars. Turk. J. of Agricultural and Natural Sciences, Sp. Issue, 2,

Hayat, S. and Ahmad, A., 2007. Salicylic Acid: A Plant Hormone. Springer Publ., Dordrecht, 401p.

Hemavathi X., Upadhyaya, C.P., Young, K.E., Akula, N., Hyun Soon, K. and Heung, J.J., 2009. Over-expression of strawberry Dgalacturonic acid reductase in potato leads to accumulation of vitamin $\mathrm{C}$ with enhanced abiotic stress tolerance, Cited from Plant Sci., 177, 659-667.

Iqbal, N., Umar, S., Khan, N.A. and Khan, M.I.R., 2014. A new perspective of phytohorm-ones in salinity tolerance: regulation of proline metabolism. Environ. Exp. Bot., 100, 34-42.

Kang, G., Li, G., Xu, W., Peng, X., Han, Q. and Zhu, Y., 2012. Proteomics reveals the effects of salicylic acid on growth and tolerance to subsequent drought stress in wheat J. Proteome Res.11, 6066-6079.

Khan, M.I.R., Syeed, S., Nazar, R. and Anjum, N. A., 2012. "An insight into the role of salicylic acid and jasmonic acid in salt stress tolerance,". In" Phytohormones and Abiotic Stress Tolerance in Plants" Khan, N.A; Nazar, R.; lqbal, N. and Anjum, N.A. (eds). (Berlin: Springer), pp. 277-300.

Khan, M.I.R., Iqbal, N., Masood, A., Per, T.S. and Khan, N.A., 2013. Salicylic acid alleviates adverse effects of heat stress on photosynthesis through changes in proline production and ethylene formation. Plant Signal Behav. 8(11), e26374.
Khan, M., Mehar, F., Per, T., Anjum, N. and Khan, N., 2015. Salicylic acid-induced abiotic stress tolerance and underlying mechanisms in plants. Front Plant Sci., 6, 462-469.

Khan, W., Prithiviraj, B. and Smith, D., 2003. Photosynthetic response of corn and soybean to foliar application of salicylates. J. Plant Physiol., 160, 485-492.

Kim G.B. and Nam, Y.W., 2013. A novel $\Delta(1)$ pyrroline-5-carboxylate synthetase gene of Medicago truncatula plays a predominant role in stress-induced proline accumulation during symbiotic nitrogen fixation. J. Plant Physiol, 170, 291-302.

Loon, C.D., 1981. The effect of water stress on potato growth, development, and yield. Am. Potato J. 58:51-69.

Ma, J.F. and Yamaji, N., 2006. Silicon uptake and accumulation in higher plants. Trends Plant Sci., 11, 392-397.

Mafakheri, A., Siosemardeh, A., Bahramnejad, B.; Struik, P.C. and Sohrabi, Y., 2010. Effect of drought stress on yield, proline and chlorophyll contents in three chickpea cultivars. Aust. J. Crop Science. 4(8), 580-585.

Maghsoudi, K., Emam, Y. and Pessarakli, M., 2016. Effect of silicon on photosynthetic gas exchange, photosynthetic pigments, cell membrane stability and relative water content of different wheat cultivars under drought stress conditions. J. Plant Nut. 7, 1001-1015.

Misra, N. and Saxena, P., 2009. Effect of salicylic acid on proline metabolism in lentil grown under salinity stress. Plant Sci. 177,181-189.

Mukhtar A., Akram, N.A., Aisha, R., Shafiq, S. and Ashraf, M., 2016. Foliar-applied ascorbic acid enhances antioxidative potential and drought tolerance in cauliflower (Brassica oleracea L. var. Botrytis). Agrochimica 60, 100-113.

Naz, H., Akram, N.A. and Ashraf, M., 2016. Impact of ascorbic acid on growth and some physiological attributes of cucumber (Cucumis sativus) plants under water-deficit conditions. Pak. J. Bot. 48, 877-883.

Nazar, R., Umar, S., Khan, N.A. and Saree, B.O., 2015. Salicylic acid supplementation improves photosynthsis and growth in mustard through changes in proline accumulation and ethylene formation under drought stress. South African J. Botany, 98, 84-94.

Noctor, G., Mhamdi, A. and Foyer, C.H., 2014. The roles of reactive oxygen metabolism in 

stress conditions

drought: not so cut and dried. Plant Physiol. 164, 1636-1648.

Payyavula, R.S., Navarre, D.A., Kuhl, J.C., Pantoja, A. and Pillai, S.S., 2012. Differential effects of environment on potato phenylpropanoid and carotenoid expression. BMC Plant Biology, 12, 1-18.

Rodríguez-Pérez, Ñústez, L. and Moreno, F., 2017. Drought stress affects physiological parameters but not tuber yield in three Andean potato (Solanum tuberosum L.) cultivars. Agronomía Colombiana 35(2), 158-170.

Saleem, S., Tahir, H.N. and Saleem, U., 2011. Study of genetic variability in maize inbred lines under irrigated and drought conditions. Int. J. Agric. Appl. Sci., 3, 80-85.

Saruhan, N., Saglam, A. and Kadioglu, A., 2012. Salicylic acid pretreatment induces drought tolerance and delays leaf rolling by inducing antioxidant systems in maize genotypes. Acta Physiol. Plant., 34, 97-106.

Shan, C.J., Tang, Y.X., Yang, W.P., Zhao, X.L., Ren, X.J. and Li, Y.Z., 2012. Comparison of photosynthetic characteristics of four wheat (Triticum aestivum L.) geno-types during jointing stage under drought stress. African J. Agric. Res, 7(8), 1289-1295.

Shi, Y., Zhang, Y., Han, W., Feng, R., Hu, Y., Guo, J. and Gong, H., 2016. Silicon Enhances Water Stress Tolerance by Improving Root Hydraulic Conductance in Solanum lycopersicum L. Front. Plant Sci., 7, 1-15.

Silva, O.N., Lobato, A.K.S., Avila, F.W., Costa, R.C.L., Oliveira Neto, C.F., Santos Filho, B.G., Martins Filho, A.P., Lemos, R.P., Pinho, J.M., Medeiros, M.B.C.L., Cardoso, M.S. and Andrade, I.P., 2012. Silicon induced increase in chlorophyll is modulated by the leaf water potential in two water-deficient tomato cultivars. Plant Soil Environ. 58, 481-486.
Vasquez-Robinet C., Mane, S.P., Ulanov, A.V., Watkinson, J.I., Stromberg, V.K., De Koeyer, D., Schafleitner, R., Willmot, D.B., Bonierbale, M., Bohnert, H.J. and Grene, R., 2008. Physiological and molecular adaptations to drought in Andean potato genotypes. J. Exp. Bot. 59, 2109-2123.

Vulavala V.K., Elbaum, R., Yermiyahu, U., Fogelman, E., Kumar, A. and Ginzberg, I., 2015. Silicon fertilization of potato: expression of putative transporters and tuber skin quality. Planta, 243, 217-229.

Wang, Z. and Huang, B., 2004. Physiological recovery of kentucky bluegrass from simultaneous drought and heat stress. Crop Sci. 44, 17291736.

Warren, C.R., 2008. Rapid Measurement of Chlorophylls with a Microplate Reader. J. Plant Nut., 31, 1321-1332.

Yildirim, E., Turan, M. and Guvenc, I., 2008. Effect of foliar salicylic acid applications on growth, chlorophyll and mineral content of cucumber (Cucumis sativus L.) grown under salt stress. J. Plant Nutr., 31, 593-612.

Zhang, Z. and Huang, R., 2013. Analysis of malondialdehyde, chlorophyll proline, soluble sugar, and glutathione content in arabidopsis seedling. Bio-protocol 3(14), e817, 1-9.

Zhu, Y. and Gong, H., 2014. Beneficial effects of silicon on salt and drought tolerance in plants. Agron. Sustain. Dev. 34, 455-472.

Zonouri, M.T., Javadi, N., Ghaderi and Saba, M.K., 2014. Effect of foliar spraying of ascorbic acid on chlorophyll a chlorophyll b, total chlorophyll, carotenoids, hydrogen peroxide, leaf temperature and leaf relative water content under drought stress in grapes. Bull. Environ. Pharmacol. Life Sci., 3, 178-184. 



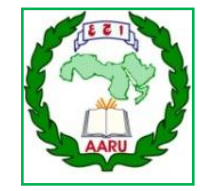

المؤتمر الرابع عشر لبحوث التنمية الزراعية،

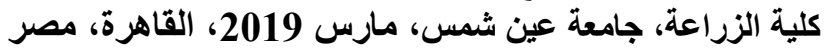

مجلا(27)، عدد (1)، عداعد خاص مارس، مارس 15-15، 2019

Website: http://strategy-plan.asu.edu.eg/AUJASCl/

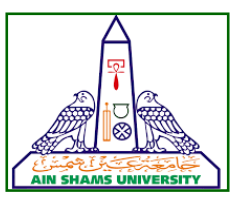

تأثير الأسكوريات والساليسيلات والسيليكات على نبات البطاطس تحت ظروف إجهاد نقص الماء

[1]

أمل عبد المنعم مصطفى 1- مصطفى إبراهيم ثروت²- دولت على سلامة2- حسنى أبو العز سلام1 1

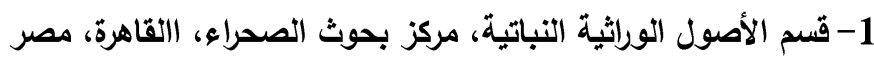

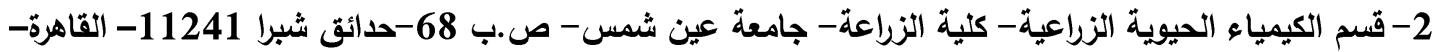

*Corresponding author: amala.mostafa@gmail.com

مصر

Received 9 October, 2018,

Accepted 28 October, 2018

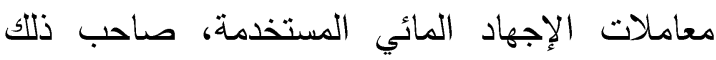

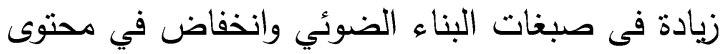

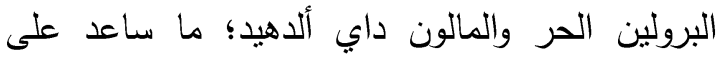

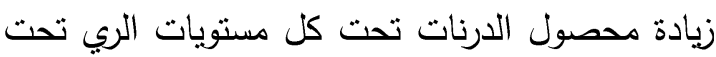
الأراسة مقارنة بالتركيزات الأخرى.

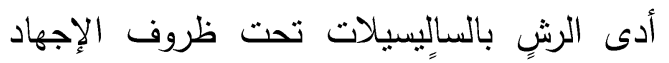

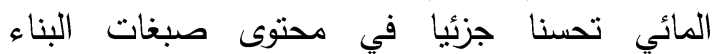
الضوئي؛ حيث أدت المعاملة بالتركيز 0.1 ملإيمولر فئر إلى زيادة في الكلوروفيل (أ) تحت جمئ باتكيع مستويات نقص الماء، كذلك كلوروفيل (ب) تحت الرئ الرئ المعتاد (الكنترون) والري كل 4 أيام، بينما أدى تلى تركيز

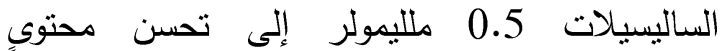
الكاروتينويدات تحت مستوى ري كل 5.

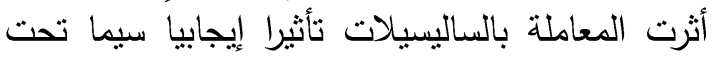

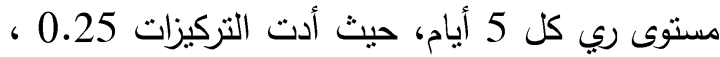
و0.5، و1.0 ملليمولر إلى زيادة في محصول الدرنات

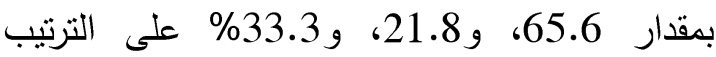
مقارنة بالكنترول، مصحوبة بإنخفاض محتوى البرولين

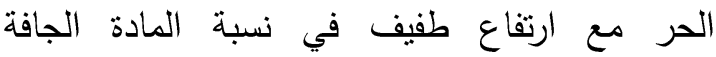

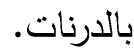

تباينت تأثيرات المعاملة بالسليكات تحت الاجهاد

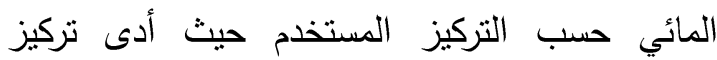
السليكات 100 جزء/مليون إلى زيادة متوسط محتوى

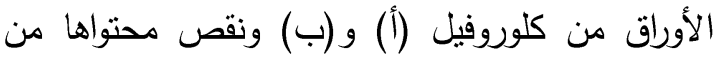
البرولين الحرمقارنة بالكنترول في كلا مستويي الإجهاد

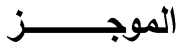

تم دراسة التغيرات البيوكيميائية المصاحبة للرش في تجربة حقلية بمعاملات مختلفة من الأسكوربات بتركيزات (0.25,0.5,1.0 ملليمولر) والساليسيلات

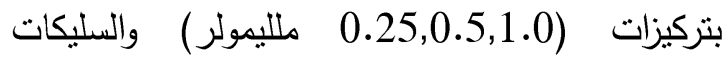
بتركيزات (100,250,500 جزءو/مليون) على نبات البطاطس (صنف سبونتا) تحت مستويات نقص الماء والتي تتمنل في الري المنتظم بفارق 3 و 4 و 5 و أيام بين الريات مقارنة بالكنترول. تم تقدير محتوى النبات من صبنغات لتبنات البناء الضوئي، والبرولين الحر، والمالونِ داي الدهيد، ونسبة

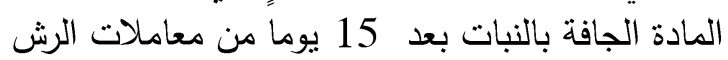
وفي نهاية الموسم تم تسجيل محصول الدرنات، وتقدير نسبة المادة الجافة فيها. أنثارت النتائج إلى وجود المانى تأثنير سلبي للإجهاد المائي على كل من محصول الدرنات ومحتوى النبات النّات والدرنات من المادة الجافة. كما أدى الإجهاد المانئي

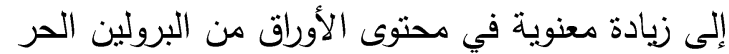

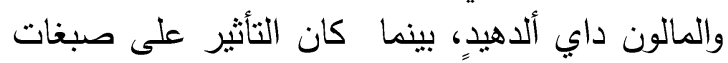
البناء الضوئي طفيفا.

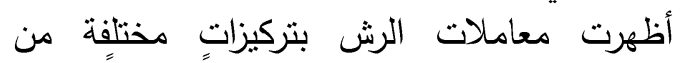

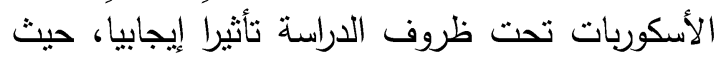

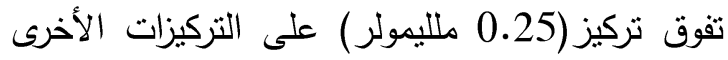

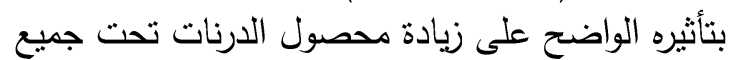

تحكيم: ا.د سامية محمود خليل

ا.د محمد احمد طه عبد الرحيم 

stress conditions

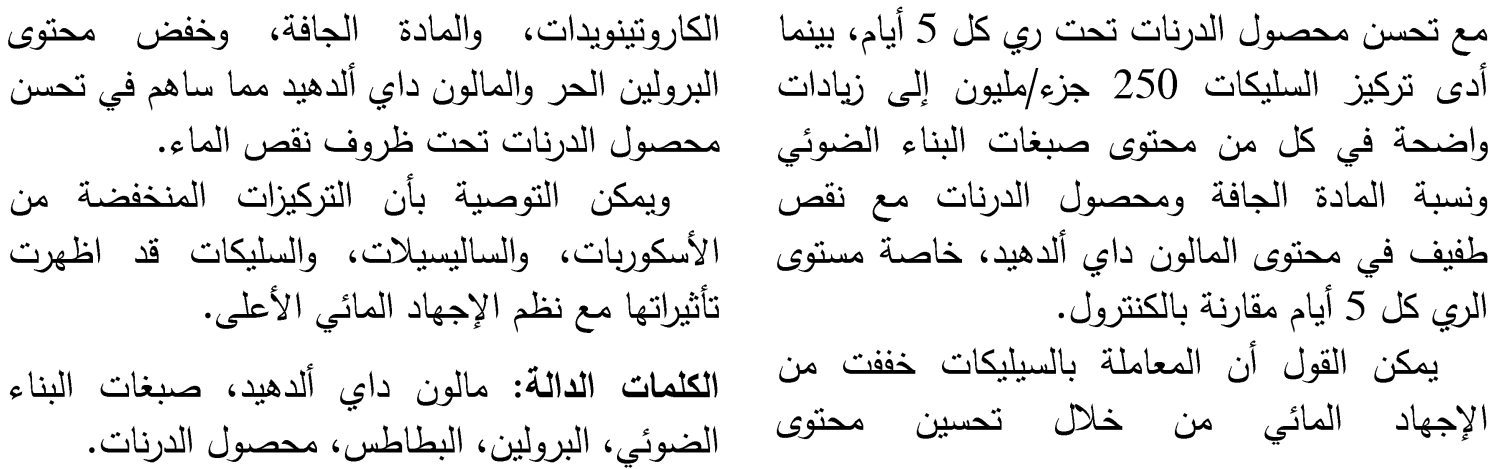

